\title{
PENGEMBANGAN KREATIVITAS DAN KOMPETENSI MAHASISWA DALAM MEMPERSIAPKAN PEMBELAJARAN BIOLOGI MATA KULIAH PERENCANAAN PENGAJARAN BIOLOGI
}

\author{
Jalilah Azizah Lubis dan Fitri Agustina Lubis \\ Pendidikan Biologi, FKIP Universitas Muhammadiyah Tapanuli Selatan \\ jalilah.azizah@um-tapsel.ac.id
}

\begin{abstract}
This study aims to find out the planning developed by students eligible to be used as materials for planning in teaching in the field, teaching planning materials taught by SCL (StudentCentered Learning) approach. Knowing the creativity of biology teaching planning with Student-Centered Learning approach, as reference material for students to be developed effectively during Field Lecture Practice (PKL) and improve learning result of teaching planning of biology student. This research is research of the development of the 4D model (four D model) with research procedure covering Define, Design, Develop and Disseminate. The data obtained are quantitative data of observer and qualitative data. Based on the results of the study, the average percentage of the five planning indicators obtained data from the average observer preparation above average teaching that is $\geq 3.00$ and categorized "Good" but in the lesson setting is still not good, with Practicality teaching has started well but the lack of student confidence in making the material and not yet understand the basic skills of teaching that must be mastered by a teacher. Analysis of learning outcomes obtained an average percentage of 93\% means students can already understand the process of making teaching planning that has been developed and effective for use in the learning process.
\end{abstract}

Keywords: Development, Creativity, Learning Outcomes, Practicality.

\begin{abstract}
Abstrak
Penelitian ini bertujuan untuk mengetahui perencanaan yang dikembangkan oleh mahasiswa layak digunakan sebagai bahan perencanaan dalam pengajaran di lapangan, materi perencanaan pengajaran diajarkan dengan pendekatan SCL (Student Centered Learning). Mengetahui kreativitas perencanaan pengajaran biologi dengan pendekatan Student Centered Learning, sebagai bahan acuan bagi mahasiswa untuk dikembangkan secara efektif pada saat Praktek Kuliah Lapangan (PKL) dan meningkatkan hasil belajar perencanaan pengajaran mahasiswa biologi. Penelitian ini adalah penelitian pengembangan model 4D (four D model) dengan prosedur penelitian meliputi Define, Designe, Develope dan Dessiminate. Data yang diperoleh berupa data kuantitatif observer dan data kualitatif. Berdasarkan hasil penelitian besar persentase rata - rata dari lima indikator perencanaan didapatkan data dari observer rata - rata persiapan pengajaran diatas rata rata yaitu $\geq 3,00$ dan dikategorikan "Baik" tetapi dalam pengaturan jam pelajaran masih kurang baik, dengan Praktikalitas mengajar sudah mulai baik tetapi kurangnya rasa percaya diri mahasiswa dalam membuat materi dan belum paham mengenai kemampuan dasar mengajar yang harus dikuasai seorang guru. Analisis hasil belajar secara umum diperoleh rata - rata persentase $93 \%$ artinya siswa sudah dapat memahami proses pembuatan perencanaan pengajaran yang telah dikembangkan dan efektif untuk digunakan pada proses pembelajaran.
\end{abstract}

Kata Kunci: Pengembangan, Kreativitas, Hasil Belajar, Praktikalitas. 


\section{PENDAHULUAN}

Kurikulum 2013 sudah dilaksanakan sejak tahun 2014, dalam pelaksanaan kurikulum terdapat perubahan paradigma dimana proses pembelajaran yang berlangsung tidak lagi terpusat pada guru (Teacher Centered Learning) tetapi pembelajaran harus terpusat pada siswa (Student Centered Learning). Mahasiswa Prodi Pendidikan Biologi UMTS merupakan mahasiswa yang sedang disiapkan untuk menjadi guru biologi. Hal ini berarti bahwa keberhasilan pendidikan biologi di sekolah dimasa yang akan datang akan banyak ditentukan oleh mereka. Jika saat ini masih banyak pembelajaran biologi yang kurang bermakna dan diaplikasikan dalam kehidupan sehari - hari, maka mahasiswa calon guru biologi yang saat ini masih berada di bangku kuliah diharapkan mampu memperbaiki keadaan ini.

Dalam proses pembelajaran banyak variabel yang menentukan tingkat kebermaknaan, salah satunya persiapan perencanaan pengajaran yang dibuat oleh guru dan media pengantar pembelajaran sehingga proses pembelajaran lebih bermakna dan lebih menarik. Diharapkan siswa dapat mengaplikasikan ilmu yang didapatkan dalam kegiatan sehari - hari. Mahasiswa calon guru biologi harus disiapkan memiliki kemampuan untuk melaksanakan proses pembelajaran yang bermakna tersebut.

Berdasarkan pengamatan awal yang dilakukan oleh dosen pengampu bahwa pelaksanaan pembelajaran perencanaan pengajaran di Prodi Biologi ditemukan kendala utama yaitu kurangnya persiapan mahasiswa dalam pelaksanaan pembelajaran dari segi materi pembelajaran, media pengantar pembelajaran sehingga mahasiswa dalam mengajar pada saat PKL (Praktek Kerja Lapangan) belum optimal mengkaji berbagai persoalan dalam pembelajaran biologi. Pentingnya persiapan ini dalam pembelajaran dapat dilihat dari komentar beberapa guru - guru di sekolah yang berperan sebagai pamong menilai mahasiswa masih belum mampu dalam mengaplikasikan ilmunya di lapangan dikarenakan kurangnya persiapan dalam menguasai materi yang disesuaikan dengan model atau metode pembelajaran didukung dengan media yang menjadikan pembelajaran menjadi lebih menarik yang menciptakan PBM yang efektif dan efisien. Dalam masalah merancang materi pembelajaran terdapat lima kategori kapabilitas yang dapat dipelajari mahasiswa, yaitu informasi verbal, keterampilan intelektual, strategi kognitif, sikap dan keterampilan motorik (Alamsyah, 2016). Pengembangan kreativitas mahasiswa ini diharapkan akan berdampak pada keterampilan atau kompetensi ketika menjadi guru kelak, baik dalam pembelajaran memberikan materi ataupun pada saat pelaksanaan praktikum. Ini sesuai dengan pernyataan Hartono (2010) Apabila mahasiswa sebagai calon guru diajar dengan perkuliahan yang berorientasi pada keluasan pemahaman materi maka kemungkinan kelak ketika mengajar di sekolah akan mengajar dengan cara itu juga.

Permasalahan lainnya yang ditemukan adalah rendahnya kemampuan berpikir mahasiswa yang terlihat dari kualitas pertanyaan dan jawaban pada saat proses pembelajaran berlangsung. mahasiswa kurang mampu menggunakan daya nalar dalam menanggapi informasi yang diterimanya. Disamping juga dalam mengembangkan potensi siswa secara aktif pada proses pembelajaran dengan membuat kelompok yang terdiri dari dua orang atau lebih, sehingga dapat menciptakan pola interaksi yang optimal, mengembangkan semangat kebersamaan pada siswa masih kurang dalam perencanaan pengajaran yang dipersiapkan (Alamsyah, 2016).

\section{METODE}

Penelitian ini dilaksanakan di Universitas Muhammadiyah Tapanuli Bagian Selatan Program Studi Biologi 
semester VI berjumlah 30 orang mahasiswa. Penelitian ini merupakan penelitian pengembangan (Research and Development), karena mengembangkan suatu perangkat pembelajaran oleh mahasiswa. Penelitian ini berupaya membuat suatu perangkat baru dalam pembelajaran, yaitu perangkat pembelajaran jenis LKS yang menggunakan model SCL. Dengan tahapan, perencanaan, observasi, dan penyebaran instrumen (Sudijono, 2012).

Instrumen penelitian yang digunakan yaitu lembar observasi keterampilan perencanaan pengajaran dan lembar aspek yang di amati pada respon siswa terhadap kegiatan pembelajaran penelitian ini memiliki dua target. Target pertama yaitu peningkatan persiapan perencanaan pengajaran mahasiswa mulai dari perencanaan program tahunan (Prota), program semester (Prosem), Silabus, RPP, dan Media, sedangkan target kedua hasil belajar mahasiswa meningkat dalam mata kuliah perencanaan pengajaran.

\section{HASIL DAN PEMBAHASAN}

Pengembangan perencanaan pengajaran digunakan penilaian instrumen berupa perlengkapan perencanaan pengajaran mahasiswa setelah itu mahasiswa melaksanakan microteaching pembelajaran yang telah di rencanakan, dimana tes ini terdiri dari dua tes, yaitu persiapan perencanaan dan test praktek pengajaran sesuai dengan perencanaan yang sudah dipersiapkan. untuk mengetahui kemampuan awal mahasiswa dalam menerapkan model pembelajaran. Data mahasiswa dalam mempersiapkan perencanaan dan sudah dilakukan penilaian oleh peneliti dan disimpulkan adalah tentang perencanaan sesuai dengan tabel.
Tabel 1: Jumlah Rata Rata Persiapan Pengajaran Mahasiswa Biologi

\begin{tabular}{lccccc}
\hline Keterangan & Prota & Prosem & Silabus & RPP & Media \\
\hline Jumlah & 103 & 102 & 101 & 98 & 94 \\
Rata rata & 3,43 & 3,4 & 3,37 & 3,27 & 3,13 \\
\hline
\end{tabular}

Keterangan : $4=$ Sangat Baik,3 = Baik 2 = Cukup, $1=$ Kurang

Berdasarkan tabel 1 didapatkan persiapan mahasiswa dalam pembuatan perencanaan sudah diatas rata rata dan dikategorikan "Baik" karena rata rata nilai sudah $\geq 3,00$ tetapi dalam pengaturan jam pelajaran masih kurang baik, karena mahasiswa belum mengetahui keluasan materi yang akan diajarkan dalam satu tahun. Sehingga mahasiswa belum tepat dalam pemberian waktu jam pelajaran sesuai mata kuliah, hal ini berimbas pada silabus dan RPP yang dibuat.

Dari segi tingkat kerapian dan kepandaian dalam menulis Prota dan prosem mahasiswa sudah dalam kategori baik. Ini dilihat dari hasil belajar mahasiswa yang masih dapat membuat prota dan prosem yang dikembangkan sesuai berapa minggu pertemuan dalam semester. Tetapi pada saat persiapan pembuatan media mahasiswa masih banyak mengunduh powerpoint dari internet sehingga pada saat menjelaskan materi di praktek siswa hanya berpatokan pada slide powerpoint yang dibuat tanpa bisa mengembangkan materi dari slide medianya tersebut. Hal ini dapat berdampak pada kemampuan mahasiswa pada saat praktek dalam pengelolaan kelas dan menguasai materi atau bahan ajar. Efek yang dihasilkan mahasiswa dalam mengajar tingkat kepercayaan dirinya sangat jauh berkurang. Hal ini dapat dilihat pada gambar 1 . 
(a)

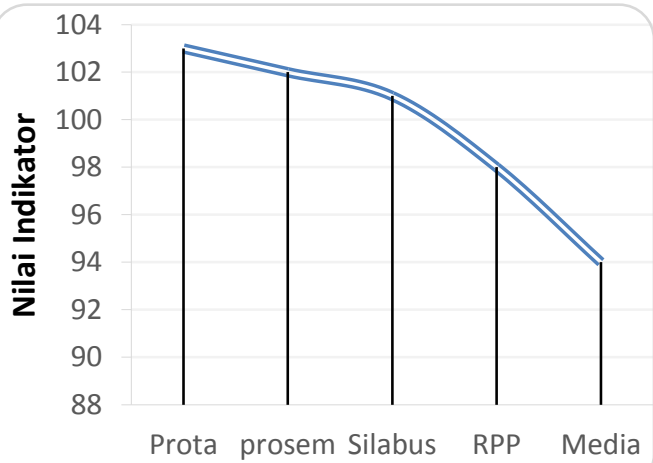

(b)

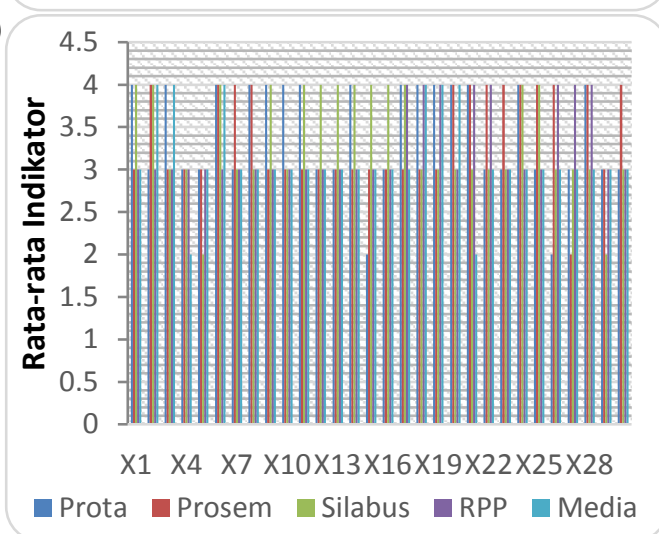

Gambar 1: (a) Jumlah nilai persiapan perencanaan pengajaran Mahasiswa, (b) Rata-rata nilai persiapan perencanaan pengajaran Mahasiswa

\section{Hasil Belajar Perencanaan} Pengajaran Mahasiswa, diakhir pelaksanaan perkuliahan, mahasiswa diberikan tes hasil belajar mengenai kemampuan siswa dalam menyelesaikan soal pada materi pokok perencanaan pengajaran yang bertujuan untuk melihat keberhasilan tindakan yang diberikan. Berdasarkan tes yang dilakukan setelah perkuliahan diperoleh hasil analisis data yang dapat dilhat pada Tabel 2.

Tabel 2: Persentase Penilaian Kognitif mahasiswa

\begin{tabular}{cccccc}
\hline \multicolumn{3}{c}{ Indikator Penilaian } & \multicolumn{2}{c}{ Ketuntasan } \\
Soal & Soal & Soal & Soal & & \\
No. 1 & No. 2 & No. 3 & No.4 & Tun & Tidak \\
tas & Tuntas \\
Pengetahuan & Pemahaman & Penerapan & Analisis & & \\
\hline $94 \%$ & $83 \%$ & $74 \%$ & $54 \%$ & 28 & 2 \\
& Rata-rata nilai 80,0 & & $93 \%$ & $7 \%$ \\
\hline
\end{tabular}

Data ini digunakan untuk mengetahui tingkat penguasaan mahasiswa terhadap materi yang telah dipelajari selama perkuliahan. Penilaian tes tertulis ini terdiri dari 4 indikator yaitu: pengetahuan, pemahaman, penerapan dan analisa. Dari tabel 2 dapat dilihat penilaian kognitif sebagai berikut.

(a)Pengetahuan

Pada indikator pengetahuan $94 \%$ siswa sudah menjawab dengan benar soal tersebut, hanya 2 orang mahasiswa yang tidak bisa menjawab soal tersebut dengan benar. Pencapaian tersebut sudah berada di atas standar minimal yaitu $78 \%$.

(b)Pemahaman

Pada indikator pemahaman ada dua nomor yaitu No.3 dan No.4 tingakat pencapaian mahasiswa sudah bagus terlihat dari No.3 83\% dan No.4 85\% mahasiswa sudah menjawab dengan benar soal tersebut. Pencapaian ini juga sudah berada di atas standar minimal yaitu $78 \%$.

(c) Penerapan

Pada indikator penerapan masih $74 \%$ mahasiswa menjawab dengan benar soal tersebut, terdapat 8 orang mahasiswa yang belum bisa dalam menjawab soal tersebut. Pencapaian ini masih berada di bawah standar minimal yaitu $78 \%$.

(d)Analisis

Pada indikator analisa tingkat pencapaian siswa sudah mulai meningkat, tapi masih dibawah standar yaitu hanya $54 \%$ mahasiswa yang bisa menjawab dengan benar soal tersebut sekitar 16 mahasiswa, masih sangat banyak siswa yang kurang mampu dalam menganalisa soal. Pencapaian ini masih sangat jauh di bawah standar minimal yaitu $78 \%$.

Dari 30 orang mahasiswa, 28 orang (93\%) yang sudah bernilai sama atau di atas KKM yaitu 78 , sisanya 2 orang (7\%) masih bernilai di bawah KKM. Rata-rata nilai sebesar 80 sudah berada di atas KKM 78. Dan persentase ketuntasan mahasiswa secara klasikal sudah diatas $75 \%$. Untuk 
lebih jelasnya dapat dilihat pada gambar grafik di bawah ini.

Tahap Perancangan (Design) yang dilakukan Mahasiswa, Pada tahap ini peneliti merancang perangkat pembelajaran berbasis SCL untuk menjelaskan kepada mahasiswa pentingnya mempersiapkan perencanaan pengajaran yang berdampak pada proses pembelajaran yang akan dilangsungkan. Perencanaan ini dimulai dengan pengembangan Prota, Prosem, Silabus dan RPP. Pembelajaran berbasis SCL diperlukan dalam pembelajaran perencanaan untuk meningkatkan kreativitas masing masing mahasiswa. (Attard et al, 2010) Perangkat yang dirancang meliputi RPP, materi ajar, lembar kerja (LK) dan alat evaluasi. Berikut ini akan diuraikan proses perancangan masing-masing perangkat pembelajaran tersebut. Pengembangan yang dilakukan antara lain :

(1)Pembuatan Prota (Program Tahunan)

Dasar pengembangan prota diambil dari kurikulum 2013 yang telah ditentukan pada Permendikbud thn 2016.

(2)Pembuatan Prosem (Program Semester) Pengembangan Program semester diambil dari kelender pendidikan masa aktif sekolah per satu semester dan dibagi sesuai SK - KD yang akan diajarkan. Dimana disini diharapkan ketelitian mahasiswa dalam menentukan jam pelajaran sesuai dengan materi yang akan diajarakan. Pembuatan prosem diharapkan pengembangan indikator materi pelajaran, sehingga didapatkan tujuan pembelajaran dapat dikembangkan oleh siswa yang akan diajarkan.

(3)Pengembangan Silabus

Pengembangan silabus dititk beratkan pada indikator dan kegiatan pembelajaran yang akan dilaksanakan oleh mahasiswa, disinilah perlu ditekankan penyesuaian pendekatan, strategi, model, dan metode pembelajaran kedalam materi pelajaran yang akan dijarkan. Sehingga dari silabus kita dapat memprediksi kegiatan dan hasil capaian yang akan didaptkan oleh para siswa.

(4)Rencana Pelaksanaan Pembelajaran (RPP)

RPP merupakan gambaran dari prosedur pembelajaran yang dijadikan panduan oleh guru dalam melaksanakan proses pembelajaran untuk mencapai kompetensi yang diharapkan. RPP berupa pedoman yang dirancang secara sistematis untuk menggambarkan skenario penyajian materi pelajaran sesuai dengan sintaks. RPP merupakan komponen penting dalam proses pembelajaran yang harus dikembangkan secara profesional.

(5)Lembar Kegiatan Siswa (LKS)

LKS adalah suatu pedoman yang dirancang oleh mahasiswa dan digunakan oleh siswa untuk melakukan kegiatan yang akan dilakukan selama proses pembelajaran berlangsung. LKS dikerjakan bersama kelompoknya masing-masing. Kegiatan dalam LKS dilakukan siswa berkelompok, agar masing-masing siswa dapat saling melengkapi kekurangan pengetahuannya. Langkah kegiatan dibuat dengan kalimat yang mudah dipahami agar siswa dapat mengikutinya dengan baik.

LKS yang dirancang bercirikan pendekatan pembelajaran berbasis CTL, LKS berisikan judul, mata pelajaran, kelas/semester, SK, KD, indikator, Tujuan kegiatan, rangkuman materi, petunjuk diskusi, dan materi diskusi. Dengan adanya LKS ini diharapkan siswa dapat mengalami proses pembelajaran secara langsung dan LKS yang dirancang tidak menuntut adanya praktikum.

(6) Alat Evaluasi

Alat Evaluasi yang dihasilkan bercirikan pendekatan pembelajaran berbasis $S C L$, alat evaluasi dibuat untuk menentukan presentase keberhasilan siswa setelah mengikuti proses pembelajaran. Alat evaluasi yang dibuat terdiri dari 5 soal essay. Hasil penelitian yang diperoleh 
sejalan dengan pendapat Muslich (2008), yang menyatakan bahwa keberhasilan siswa akan sangat tergantung dari pemanfaatan potensi yang dimiliki, karenanya keaktifan mahasiswa dalam menjalani proses belajar mengajar merupakan salah satu kunci keberhasilan pencapaian tujuan pendidikan.

\section{Hasil Belajar Perencanaan} Pengajaran Mahasiswa, Seberapa jauh mahasiswa dalam menguasai materi ajar yang telah diajarkan dalam 14 kali pertemuan, diberikan tes hasil belajar ranah kognitifpada pertemuan ke 8 dan ke -16 . Pemberian tes dilakukan dua kali yaitu tes formatif yang dilakukan setelah kegiatan pembelajaran dilaksanakan.

Hasil belajar yang diperoleh dari nilai rata kelas dibandingkan dengan KKM yaitu 78 maka rata-rata hasil belajar yang diperoleh yaitu 80,0 dengan ketuntasan kelas 93\%. Ini berarti masih ada mahasiswa yang tidak tuntas dalam pembelajaran perencanaan pengajaran dimana pada saat soal menganalisa dan aplikasi mahasiswa tersebut masih kurang daya nalar untuk mengembangkan perencanaan pengajaran. Seperti pada saat menjawab soal tentang bagaiman perencanaan pembelajaran yang akan anda buat jika mengajar dilokasi yang terisolir dan berada di daerah pelosok. Hal ini terjadi karena 2 orang mahasiswa tersebut belum banyak memiliki pengalaman, minat untuk mengetahui dan motivasi yang tinggi untuk merencanakan pengajaran. Sedangkan mahasiswa yang lain minat dan motivasi belajar muncul karena mahasiswa menyukai pembelajaran berbasis $C T L$ dimana mahasiswa lebih aktif menemukan sendiri konsep materi perencanaan pengajaran melalui proses pembelajaran yang berlangsung, hal ini didukung oleh pendapat Gulo (2008), yang menyatakan bahwa kegiatan inkuiri salah satu komponen $(C T L)$ dapat meningkatkan keaktifan siswa dalam proses pembelajaran sehingga tercapainya ketuntasan belajar kognitif siswa.
Dari segi ranah psikomotor, mahasiswa dilihat dari membaca hasil pembuatan dan petunjuk LKS, berperan aktif dalam menjawab pertanyaan didalam LKS, mengumpulkan data, berpartisipasi dalam kelompok, mampu mengemukakan pendapat dan dapat menarik kesimpulan. Berdasarkan data hasil belajar ranah psikomotor menunjukan bahwa mahasiswa sudah mampu menciptakan LKS tersendiri dan dimasukkan dalam kategori baik. Hasil yang diperoleh memperlihatkan bahwa model pembelajaran berbasis CTL sebagai pembelajaran yang mempersiapkan siswa untuk memperoleh informasinya sendiri serta mampu mengeluarkan pendapat dan kesimpulan (Johnson, 2007).

\section{SIMPULAN}

Berdasarkan hasil data dan praktek mengajar yang dilaksanakan diperoleh kesimpulan persiapan mahasiswa dalam pembuatan perencanaan pengajaran sudah diatas rata rata $\geq 3,00$ dan dikategorikan "Baik" tetapi dalam pengaturan jam pelajaran masih kurang baik, karena mahasiswa belum mengetahui keluasan materi yang akan diajarkan dalam satu semester. Sehingga mahasiswa belum tepat dalam pemberian waktu jam pelajaran sesuai mata kuliah, hal ini berimbas pada silabus dan RPP yang dibuat. Sedangkan praktikalitas mengajar sudah mulai baik tetapi kurangnya rasa percaya diri mahasiswa dalam membuat materi dan belum paham mengenai kemampuan dasar mengajar yang harus dikuasai seorang guru. Dari segi hasil belajar mahasiswa dengan KKM yaitu 78 maka rata-rata hasil belajar yang diperoleh yaitu 80,0 dengan ketuntasan kelas 93\%. Ini berarti masih ada mahasiswa yang tidak tuntas sebesar $7 \%$ dalam pembelajaran perencanaan pengajaran dimana pada saat soal menganalisa dan aplikasi mahasiswa tersebut masih kurang daya nalar untuk mengembangkan perencanaan pengajaran. 


\section{UCAPAN TERIMA KASIH}

Penulis ucapkan terimakasih Universitas Muhammadiyah Tapanuli Selatan (UM-Tapsel) yang telah membiayai penelitian ini, kepada Lembaga Penelitian dan Pengabdian Masyarakat (LPPM UMTapsel) yang telah dan memfasilitatori pelaksanaan penelitian. Semua yang memfasilitasi pelaksanaan penelitian di UM-Tapsel dan semua yang tidak bisa penulis sebutkan satu persatu dalam naskah ini.

\section{DAFTAR PUSTAKA}

Attard, Angele., emma di iorio., koen geven., and robert santa. (2010). Student Centred Learning, Toolkit for students Staffs, and Higher Education Institution. Education International and the European Student Union, Brussel, Belgia. (Penerjemah Prof. Dr. Dede Rosyada, MA).

Alamsyah,Nur. (2016). Penerapan Pendekatan Saintifik Untuk Meningkatkan Kreativitas Dan Hasil Belajar Siswa Dalam Mata Pelajaran IPA. Jurnal Pendidikan Vol.1, No.1. ISSN: 2527-6891.
Hartono, (2010). Statistik Untuk Penelitian, Yogyakarta: Pustaka Pelajar.

Harianti, A. Dkk. (2014). Pengembangan Kreativitas Mahasiswa Dengan Menggunakan Metode

Brainstorming Dalam Mata Kuliah Kewirausahaan. Jurnal Manajemen. Vol.13, No.2.

Johnson, Elaine. (2007). Contextual Teaching \& Learning; Menjadikan Kegiatan Belajar-Mengajar Mengasyikan dan Bermakna. Bandung, MLC.

Muslich, Masnur. (2008). KTSP Pembelajaran Berbasis Kompetensi Dan Kontekstual.Jakarta: PT. Bumi Aksara.

Sudijono, A. (2012). Pengantar Statistik Pendidikan. Jakarta. PT. Raja Grafindo Persada.

Gulo, W. (2008). Strategi Belajar dan Pembelajaran. Jakarta: PT. Grasindo. 